\title{
アルキル鎖長の異なる酸性アゾ染料と シクロデキストリンとの相互作用
}

\author{
実践女子大学 家政学部 軽部 幸恵・飯島 俊郎
}

\section{Interaction of Acid Azo Dyes Having Alkyl Group with Cyclodextrines}

\author{
Yukie Karube and Toshiro Iijima
}

Faculty of Home Economics, Jissen Women's University, 4-4-1, Oosakaue, Hino, Tokyo, 191 Japan

\begin{abstract}
The interaction of acid azo dyes having alkyl chain groups of different length with $\alpha-\beta$ - and $\gamma$-cy clodextrines $(C D)$ in aqueous solution was investigated by means of the visible absorption spectra at different temperatures. The presence of $C D\left(1 \times 10^{-6}-10^{-2} \mathrm{~mol} / \mathrm{L}\right)$ in the dye solution $\left(5 \times 10^{-5} \mathrm{~mol} / \mathrm{L}\right)$ changed the absorp tion spectra, and the degree of the change was in an order of the increasing alkly length in the dyes. With an increase in the concentration of $\mathrm{CD}$, the absorption spectra changed keeping an isosbestic point. The stoichiometry of the binding was confirmed as equimolar by a continuous variation method. Upon assuming the molar ratio of the complex as $1: 1$, the binding constants were calculated by a nonlinear least-squares method. The mode of the interaction was estimated as an inclusion type. The presence of the alkyl chains in the dye molecule increased the binding constant. The fitness of the dye to the cavity of $C D$ was suggested to affect the binding constant. Based on the temperature dependence of the binding constants at different temperatures, the compensation relation between entropy and enthalpy changes of binding was found and the contribution of entropy to the process was discussed.
\end{abstract}

(Received February 16. 1994)

\section{1. 楮旁}

グルコースが $\alpha-1 ４ 4$-ダルコシド結合した環状オり コ糖であるシクロデキストリン（以下 CD と略記する） はその特異な包接化合物形成能力によって知られ、多く の研究が行われて来た。これらは二三の成書 $[1,2] に$ しい。激粉の醉素作用により作られるCD は現在は工業 生産が行われ、ここ十余年の間に多方面の分野で利用研 究が行われてきた $[3,4]$ 。初期には包接による低分子化 合物の取り込み作用が，香料，医薬品の徐放などに応用 された。最近は $\mathrm{CD}$ (グルコースが6，7，8個環状結 合した $\alpha, \beta, \gamma$-体が基本) に化学反応を行って水溶 性を高めた化学修飾 CD は，紐胞接着能力がすぐれ，分 子認識や医薬の分野で，例えばDDS（薬物送達システ ム）などに向けて多くの広用研究が行われている。食品 分野では，没粉や大豆加工品にみられる特異な臭気の除 去, 緑色野菜の色素の安定化などの機能保持の試みが見
られる。化粧品分野では，上記の香料や虫歯予防成分の 保持によるロ内用品としての応用がある。

化学工業分野での応用も多い。包接化合物形成の場が 疎水性であることから，エステルやアミドの加水分解の 触媒作用が期待され，数多くの研究が報告されている [5.6]。さらにこの疎水場を高分子鎖に共有結合で持た せて人工酵素の構築が報告されている $(7) 。$

被服に関した例としては CDに芳香物質を包接させて 消臭加工棛として用いる試み[8，9]がある。染色関係で は染料を包接して緩染助剂の効果を検討した研究がある $[10,11]$ 。即ち, 啮沢らは4-アミノアゾベンゼン誘導体 $/ \beta-\mathrm{CD}$ 水溶液加のナイロン染色における楥染効果 を見い出した。また最近，洗浄系に於けるCDの油性污 れ除去効果が検討された[12]。

$\mathrm{CD}$ と低分子化合物との包接相互作用に関する数多く の研究の中で，染料や界面活性剂(13)をゲストにした報 告す多い。原田(14]はメチルオレンジのナトリウムおよ 
びカリウム塩との忋接化合物の結晶構造の解析を行い， アゾ基とベンぜン環は空洞内に、ジメチルアミノ基とス ルホン酸基は空洞外に位置していることを示した。

ゲストとしてメチルオレンジはよく採りあげられ，例 えばその水溶液中 $(0.1 \mathrm{M}$ リン酸楥衝液， $\mathrm{pH} 6.75, \mathrm{CD}$

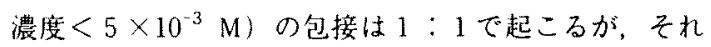
以上の濃度では $1 ： 1$ 以外のモル比をとること, $1 ： 1$ 包接化合物の解難定数 $\left(25{ }^{\circ} \mathrm{C}\right)$ は $2.2 \times 10^{-4} \mathrm{~mol} / \mathrm{L} て ゙$ あることが報告されている[15]。最近, Tawarahは $\alpha$-,

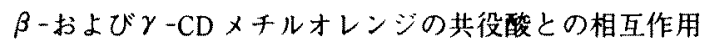
をUV吸収スペクトルで調べ結合の熟力学的諸量を求め た。 $\gamma$ ーではスペクトル変化は見られす， $\alpha$ ーおよび $\beta$ については前者がより安定な包接化合物をつくることを 見いだしている(16)。また $\boldsymbol{a}$-CDによるアソサリチル

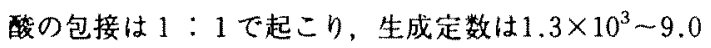
$\times 10^{3} \mathrm{~L} / \mathrm{mol}\left(25^{\circ} \mathrm{C}\right)$ が与えられている(17)。次に CD の灴洞の大きさと包接能との関係では, アソ基の両側に ナフタレン核を持つアゾ染料は $\alpha-\mathrm{CD}$ と包接化合物を 作らない[18]ことは興味をひく。また空洞の大きさから， $\alpha-\mathrm{CD}$ とは包接合物を作れないアゾ染料も $\beta-や \gamma-C D$ とは作り得ることを示す報告例 [19]もある。

本研究は，その水溶液の性質 (20)，ナイロンに対する 染着性(21)について既に報告したアルキル鎖を持つ酸性 染料と $\alpha-\beta$ - $\beta$-および $\gamma-\mathrm{CD}$ との包接平衡を調べ，そ の相互作用機構を明らかにしたものである。

\section{2. 実医}

\section{1 材料}

CD は東京化成侏より購入した試薬（GR）をそのまま 用いた。使用にあたっては，標準調湿状態 $(65 \%$ RH) の水分率を測定し，水溶液調製の際は乾燥重量換算で正 確に濃度を定めた。

$\begin{array}{lr}\alpha-\mathrm{CD}(\mathrm{CDA}) & \text { 水分率 } \\ \beta-\mathrm{CD}(\mathrm{CDB}) & 2.53 \% \\ \gamma-\mathrm{CD}(\mathrm{CDG}) & 2.77 \% \\ - & 7.35 \%\end{array}$

ここで水分率は (水分) / (水分十絶乾量) で表す。 染料は下图に示すようにアルキル鎖長の異なる3種を 用いた。これらの合成，精製は，既報 $(20,21) の$ 通りで ある。

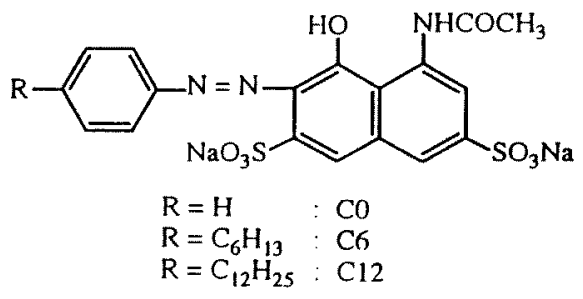

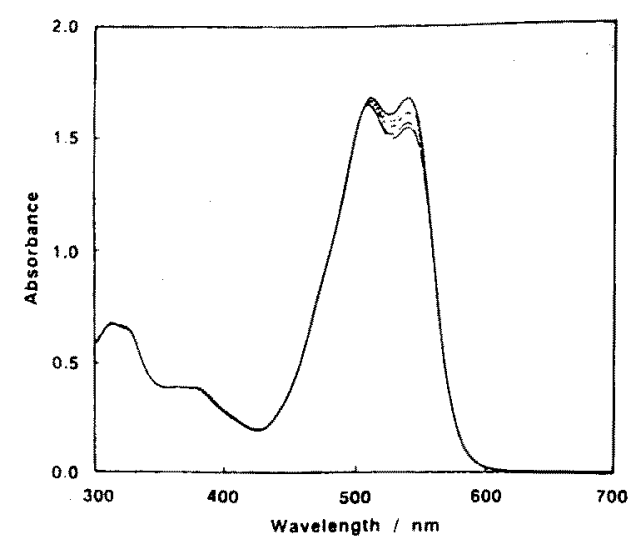

Fig. 1 Absorption spectra in aqueous solution (C6): Dye concentration, $5.00 \times 10^{-5} \mathrm{~mol} / \mathrm{L} ; \mathrm{CDG}$ concentration. $0.00,3.47 \times 10^{-4}, 1.02 \times 10^{-3}, 2.50 \times 10^{-3}$ and $6.72 \times$ $10^{-3} \mathrm{~mol} / \mathrm{L}$ in increasing order.

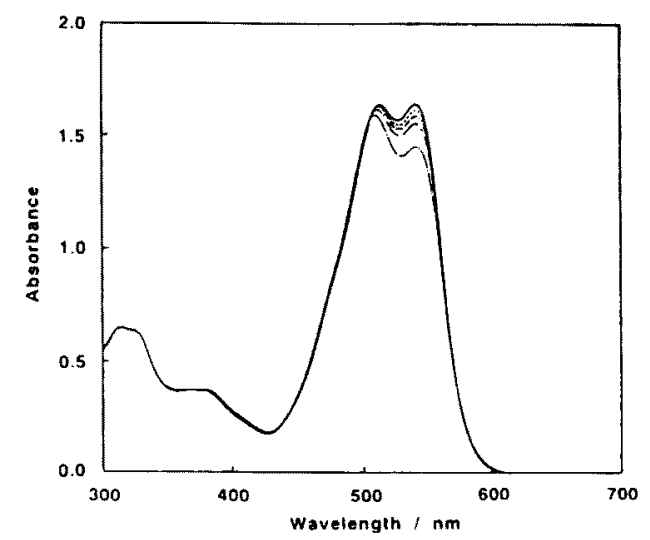

Fig. 2-a Absorption spectra in aqueous solution (C12): Dye concentration, $5.00 \times 10^{-5} \mathrm{~mol} / \mathrm{L} ; \mathrm{CDG}$ concentration, $0.00,5.00 \times 10^{-6}, 7.50 \times 10^{-6}, 1.00 \times 10^{-5}$ and $2.00 \times$ $10^{-5} \mathrm{~mol} / \mathrm{L}$ in increasing order.

水はオートスチール（ヤマト科学侏WA-32）により 蒸留後, イオン交換した純水 (此導電率 $<0.3 \mu \mathrm{S} / \mathrm{cm}$ ) を用いた。

\section{2 方 法}

染料濃度を約 $5.00 \times 10^{-5} \mathrm{~mol} / \mathrm{L}$ (精科) に固定して, $\mathrm{CD}$ 浱度を $10^{-6}-10^{-2} \mathrm{~mol} / \mathrm{L}$ の範囲で変えて試料溶液を調 製した。なお電解質の影響を避けるため，楥衝液は用い なかった。試料溶液の $\mathrm{pH}$ は吸収スペクトル測定前後に 測り6-5の範囲内の变動であることを確かめ、スベク トルに影辡を与えないものと判断した。吸収スペクトル 測定は自記分光光度計 MPS-2000（島津）により，温度 10-45 Cの範用で \pm 0.05 距保って行なった。 


\section{3. 結果と考察}

染料の吸収スペクトルは CD の存在により変化するが， その変化は C 0では少なく，C6 と 12 では大きく現れ た。変化の例を図1，2に示す。図に見ら机るようにス ペクトルは等吸収点をとりながら変化する。極大吸収波 長に扩ける分子吸光係数の濃度による変化を図 3 に示す。 この変化は CD と染料とのなんらかの相互作用の結合 平衡によるものと推定される。そこで始めに，結合体の モル比を連続変化法によって決定した。

いま CD, 染料（D）混合溶液において式 1 の結合平 衡が成り立つとする。

$\mathrm{mD}+\mathrm{nCD} \rightleftharpoons \mathrm{D}_{\mathrm{m}} \cdot \mathrm{CD}_{\mathrm{n}}$

$\mathrm{D}_{\mathrm{m}} \cdot \mathrm{CD}_{\mathrm{n}}$ は $\mathrm{CD} \mathrm{n}$ モルとD $\mathrm{m}$ モルとから成る結合体

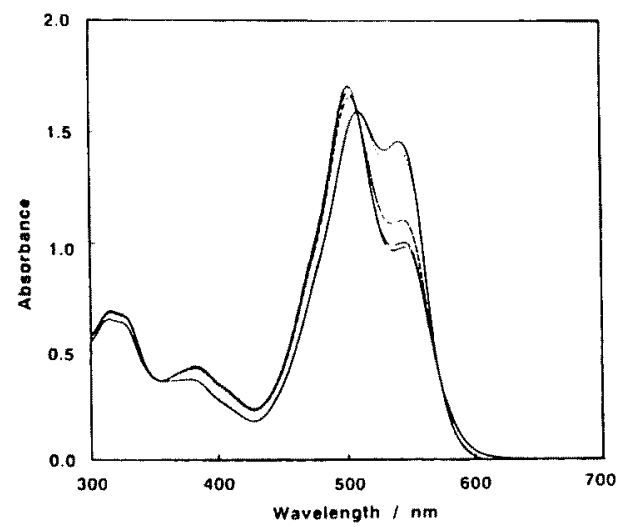

Fig. 2-b Absorption spectra in aqueous solution (C12): Dye concentration, $5.00 \times 10^{-5} \mathrm{~mol} / \mathrm{L}$; CDG concentration, $2.00 \times 10^{-5}, 2.50 \times 10^{-5}, 9.92 \times 10^{-5}, 2.29 \times 10^{-4}, 5.04$ $\times 10^{-4} \mathrm{~mol} / \mathrm{L}$ in increasing order.

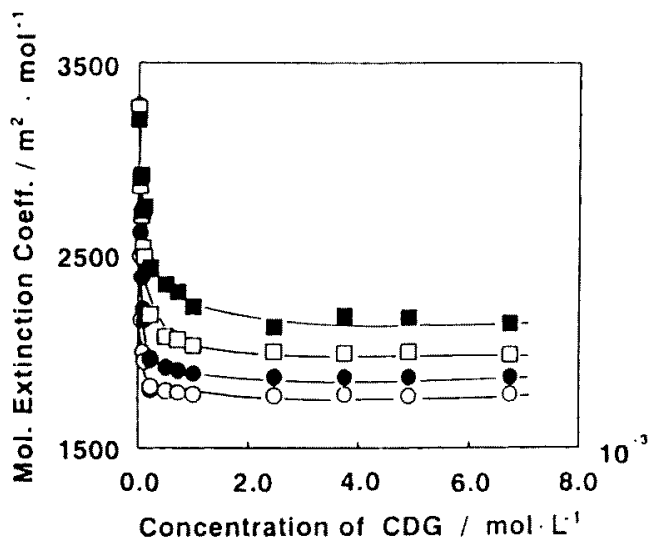

Fig. 3 Molar extinction coefficient at $540 \mathrm{~nm}$ vs. CDG concentration $(\mathrm{C} 12)$ : Temperature $\left({ }^{\circ} \mathrm{C}\right) ; 15 ; \mathrm{O} ; 25$;

O. 35: 45 ;
である。ここで CD と D との合計の濽度を一定に保って， そのモル比を変化させると図 4 が得られ，結合体の生成

量最大（すなわち結合による吸光度変化最大）のときの

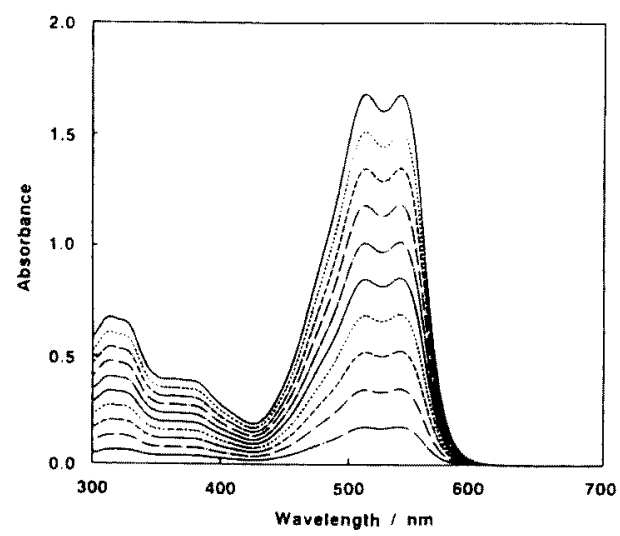

Fig. 4 Absorption spectra in various molar ratio (C6): Total concentration, $5.00 \times 10^{-5} \mathrm{~mol} / \mathrm{L}$; molar ratio (C6/CGD), $1.0,0.9,0.8,0.7,0.6,0.5,0.4,0.3,0.2,0.1$ and 0.0 in increasing order.

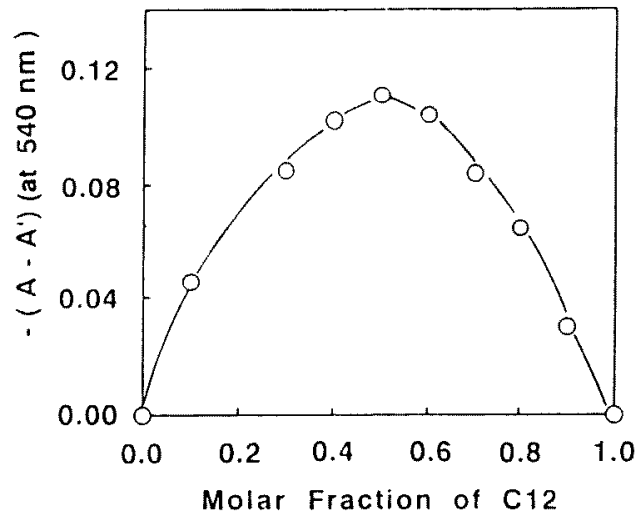

Fig. 5 Continuous variation plot(C6/CDG, $\left.25^{\circ} \mathrm{C}\right)$.

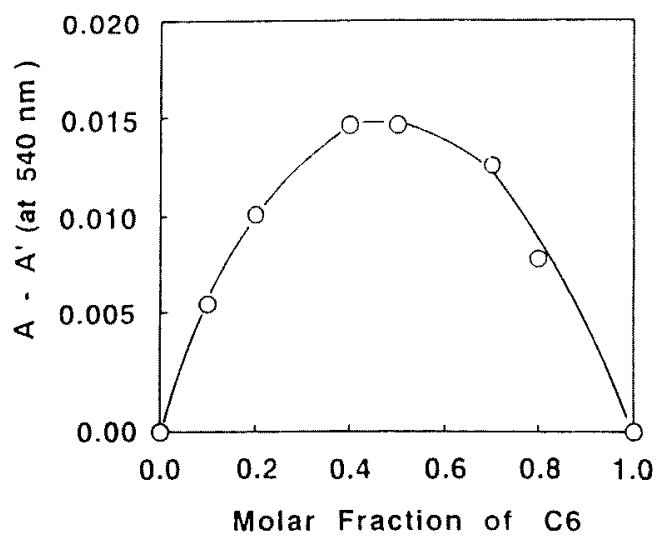

Fig. 6 Continuous variation plot $\left(\mathrm{C} 12 / \mathrm{CDG}, 25^{\circ} \mathrm{C}\right)$. 
$\mathrm{CD}$ と D のモル比は生成した結合体のモル比 $\mathrm{m} / \mathrm{n}$ に等 しいことになる $(22)$ 。結合量は極大吸収波長の吸光度に より決定した。結果を図 5，6に例示する。維軸の $A$ は式1の平衡が成立したときの吸光度, $A^{\prime}$ は相互作用 が無いときの吸光度である。図に見られるようにモル比 0.5 で極値をとり，結合体は等モル比 $\mathrm{m}=\mathrm{n}$ であること がわかる。ここで $\mathrm{m} ＼textrm{n}$ は $1 ： 1 に$ 限らない。この比は 吸光度の波長を変えても， $\mathrm{CD}$ とDの合計浱度を変えて も変わらない。本実験では合計濃度を $5.00 \times 10^{-5} \mathrm{~mol} / \mathrm{L}$ として行った。

溶液中で包接化合物ができる時， $\mathrm{CD}$ (ホスト) とゲ ストとのモル比は通常 1：1であるが例外として長鎖脂 肪酸[23]，4-ビフェニルカルボキシラート[24]と CDA が1：1以外のモル比をとることが報告されている。そ こでまず式 2 のように1：1を仮定して実験值（図 3）をどのように再現できるかを検討した。

$\mathrm{D}+\mathrm{CD} \rightleftharpoons \mathrm{D} \cdot \mathrm{CD}$

このような二成分相互作用系の平衡定数 Kを求める式 は多く提出されている[25]。中でも Benesi-Hildebrand

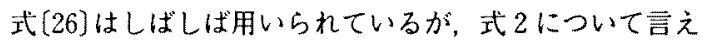
ば、 ( $\mathrm{CD}$ の全濃度) 》(D の全濃度)、従って ( $\mathrm{CD} の$ 全濃度)》(結合したD種の港度)により表される近 似の条件が含まれていて，本研究の系についての正確な 取り扱いには適しない。

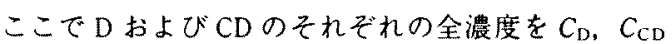
とする。 $C_{\mathrm{D}}$ のうち結合種, 非結合種（遊離種）の濃度 をそれぞれ $C_{\mathrm{Db}} ， C_{\mathrm{Dr}}$ とする。

$$
C_{\mathrm{D}}=C_{\mathrm{Db}}+C_{\mathrm{Df}}
$$

結合平衡定数を $K$ とすれば式 4 が得られる。

$$
C_{\mathrm{Db}}=K\left(C_{\mathrm{CD}}-C_{\mathrm{Db}}\right) C_{\mathrm{Dr}}
$$

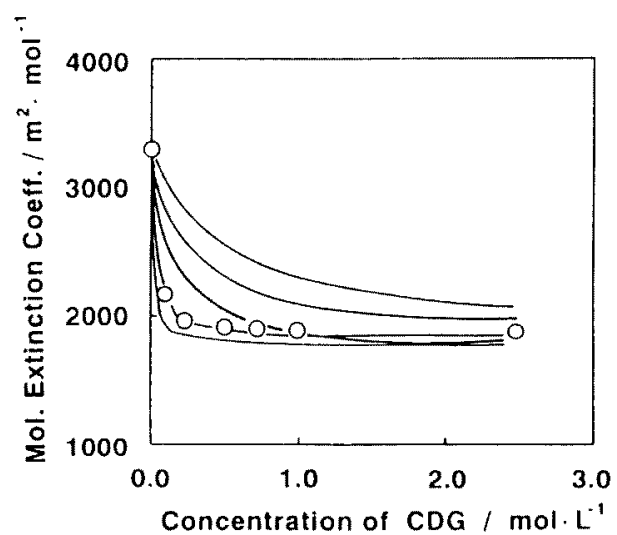

Fig. 7 Calculation of binding constant $(\mathrm{C} 12 / \mathrm{CDG}, 25$ $\left.{ }^{\circ} \mathrm{C}\right)$ : $\bigcirc$. experimental value; binding constant, $2 \times 10^{3}, 5$ $\times 10^{3}, 2 \times 10^{4}, 2 \times 10^{5}, 5 \times 10^{5} \mathrm{~L} / \mathrm{mol}$ in increasing order.
また観測される試料溶液の吸光度 $A_{\mathrm{obs}}$ は式 5 で表わ されるから、

$$
\begin{aligned}
& A_{\mathrm{obs}}=\varepsilon_{\mathrm{f}} \cdot C_{\mathrm{Di}}+\varepsilon_{\mathrm{b}} \cdot C_{\mathrm{Db}} \\
& C_{\mathrm{Db}} \text { は式 } 6 \text { で与えられる。ここで } \varepsilon_{\mathrm{f}}, \varepsilon_{\mathrm{b}} \text { はそれぞれ, }
\end{aligned}
$$

\begin{tabular}{|c|c|c|c|c|}
\hline $\mathrm{CDA}$ & $\mathrm{CO}$ & 15 & $\sim 0.4$ & 3220 \\
\hline $\mathrm{CDA}$ & $\mathrm{CO}$ & 25 & -0.4 & 3180 \\
\hline $\mathrm{CDA}$ & C6 & 10 & 6.0 & 3600 \\
\hline CDA & $\mathrm{C} 6$ & 15 & 5.4 & 3480 \\
\hline CDA & $\mathrm{C} 6$ & 25 & 4.1 & 3530 \\
\hline CDA & C6 & 35 & 3.3 & 3500 \\
\hline $\mathrm{CDA}$ & $\mathrm{C} 6$ & 45 & 2.5 & 3490 \\
\hline CDA & $\mathrm{C} 12$ & 10 & 20.0 & 3510 \\
\hline $\mathrm{CDA}$ & $\mathrm{C} 12$ & 15 & 19.5 & 3510 \\
\hline $\mathrm{CDA}$ & $\mathrm{C} 12$ & 25 & 15.6 & 3510 \\
\hline $\mathrm{CDA}$ & $\mathrm{C} 12$ & 35 & 12.0 & 3480 \\
\hline CDA & $\mathrm{C} 12$ & 45 & 9.3 & 3460 \\
\hline $\mathrm{CDB}$ & $\mathrm{CO}$ & 15 & -0.4 & 3200 \\
\hline $\mathrm{CDB}$ & $\mathrm{CO}$ & 25 & -0.3 & 3150 \\
\hline $\mathrm{CDB}$ & $\mathrm{CO}$ & 35 & $\sim 0.25$ & 3110 \\
\hline $\mathrm{CDB}$ & C6 & 10 & 37.6 & 3420 \\
\hline $\mathrm{CDB}$ & C6 & 15 & 15.0 & 3410 \\
\hline $\mathrm{CDB}$ & $\mathrm{C} 6$ & 25 & 5.0 & 3400 \\
\hline $\mathrm{CDB}$ & $\mathrm{C} 6$ & 35 & 4.0 & 3340 \\
\hline $\mathrm{CDB}$ & $\mathrm{C} 6$ & 45 & 2.5 & 3310 \\
\hline $\mathrm{CDB}$ & $\mathrm{C} 12$ & 10 & 7.2 & 3490 \\
\hline $\mathrm{CDB}$ & $\mathrm{C} 12$ & 15 & 6.0 & 3490 \\
\hline CDB & $\mathrm{C} 12$ & 25 & 5.2 & 3340 \\
\hline $\mathrm{CDB}$ & $\mathrm{C} 12$ & 35 & 4.7 & 3420 \\
\hline $\mathrm{CDB}$ & $\mathrm{C} 12$ & 45 & 4.5 & 3390 \\
\hline CDG & $\mathrm{Co}$ & 15 & -0.5 & 3240 \\
\hline$C D G$ & $\mathrm{CO}$ & 25 & $\sim 0.35$ & 3210 \\
\hline CDG & $\mathrm{CO}$ & 35 & -0.3 & 3185 \\
\hline $\mathrm{CDG}$ & $\mathrm{C} 6$ & 10 & 1.1 & 2780 \\
\hline $\mathrm{CDG}$ & C6 & 15 & 1.0 & 2860 \\
\hline $\mathrm{CDG}$ & $\mathrm{C} 6$ & 25 & -0.76 & 3020 \\
\hline$C D G$ & $\mathrm{C} 6$ & 35 & -0.66 & 3140 \\
\hline$C D G$ & C6 & 45 & -0.6 & 3200 \\
\hline CDG & $\mathrm{C} 12$ & 15 & 201.0 & 1780 \\
\hline CDG & $\mathrm{C} 12$ & 25 & 100.0 & 1880 \\
\hline CDG & $\mathrm{C} 12$ & 35 & 45.0 & 2000 \\
\hline CDG & $\mathrm{C} 12$ & 45 & 12.3 & 2150 \\
\hline
\end{tabular}

Tabie 1 Binding Constants

Host Guest Temp. $/{ }^{\circ} \mathrm{C} K \times 10^{-3} / \mathrm{L} \cdot \mathrm{mol}^{-1} \varepsilon_{\mathrm{b}} / \mathrm{m}^{2} \cdot \mathrm{mol}^{-1}$ 
染料の遊蜼種，結合種の分子吸光係数である。

$$
C_{\mathrm{Db}}=C_{\mathrm{D}}\left(\varepsilon_{\mathrm{obs}}-\epsilon_{\mathrm{f}}\right) /\left(\varepsilon_{\mathrm{b}}-\varepsilon_{\mathrm{s}}\right)
$$

従って $C_{\mathrm{Db}}$ に関する 2 次式である式 4 の根と, 式 6 の右 辺を等置して得られる式は，巨。および $K$ を末知数とし て含み，その他は実測値として与えられる。民。例 えば図 3 の実測值から $C_{\mathrm{CD}} \rightarrow \infty$ として推定が可能である。 このようにして，Kの值を次々に变え与えて測定值 $A_{\mathrm{obs}}$ あるいは $\varepsilon_{\mathrm{obs}}\left(=A_{\mathrm{obp}} / C_{\mathrm{D}}\right)$ に対する $C_{\mathrm{CD}}$ の関係 (例えば図 3 )を最も良く再現する $\varepsilon_{\mathrm{b}} ， K$ を定めるこ とができる。これは非線形最小二乗法の計算プログラム によっても，また EXCELなどの表計算プログラムのソ フトによっても演算できる。本研究では雨者を併用した。 未知数 $K$ の値のあたりをつけるに後者が便利であった。 前者のプログラムは信州大学濱田州博氏のものを用いた。 計算結果の例を図 7 に示す。

このようにして， $\varepsilon_{\mathrm{b}} ， K$ を適当に選ぶことにより， 染料および CD の活量〔27〕を濃度に等しいと置く以外は 近似を用いずに，式 2 に基礎を置いて実験結果をよく再 現する結合定数を定めることができた。これにより，結 合体のモル比は $1 ： 1$ と推定した。

一方，C 0，C 6，C12とD-グルコースとの相互作用 は分光学的には検知できない。即ち， $\mathrm{C} 12$ (または C 0 ， C6）浱度を $5 \times 10^{-5} \mathrm{~mol} / \mathrm{L}$ に保ちD-グルコース濃度 を $1 \times 10^{-4}-1 \times 10^{-2} \mathrm{~mol} / \mathrm{L}$ に変之た水溶液の吸収スペ クトルは700-300 nmの範囲で変化が見られない。この ことから，用いた染料と $\mathrm{CD}$ とは環状構造の外側で相互 作用するのではないと考えられる。

用いた総ての $\mathrm{CD}$ ，染料の組み合わせについて得られ た平衡定数 $K$ を表1にまとめて示す。計算にはをれぞ れの染料の極大吸收波長の吸光度を用いたが、波長によ らずKの計算値は一定となることも別に確かめた。

C 0 染料は，前記のようにいずれの CDについても吸 収スペクトルの変化は少なく，計算された $K$ は250-500 $\mathrm{L} / \mathrm{mol}$ 程度の低い值であり，その計算值の信頼度は低い。 表中一を付したのは約の意味である。C 0 と他のC 6 ，

Table 2 Cavity Sige of $C D|1|$

\begin{tabular}{|c|c|c|c|c|}
\hline \multirow{2}{*}{$\mathrm{CD}$} & \multirow{2}{*}{$\begin{array}{l}\text { Number of } \\
\text { Glucose }\end{array}$} & \multirow[b]{2}{*}{ Mol. wt. } & \multicolumn{2}{|c|}{ Cavity Size (nm) } \\
\hline & & & In. dia. ${ }^{\text {a) }}$ & Depth \\
\hline$\alpha$ & 6 & 972 & $0.45^{\text {b) }}$ & $0.67^{\mathrm{b})}$ \\
\hline$\beta$ & 7 & 1135 & $-0.70^{c)}$ & $-0.70^{c}$ \\
\hline$\gamma$ & 8 & 1297 & $\left.-0.85^{c}\right)$ & $-0.70^{c)}$ \\
\hline
\end{tabular}

a) Inner diameter. ${ }^{\text {b) }}$ X-ray diffraction. ${ }^{\text {c) }}$ Molecular model.

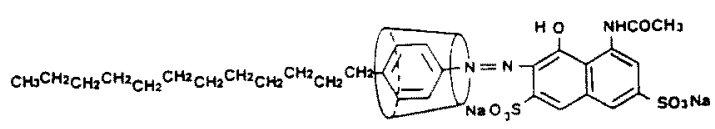

Fig. 8 Proposed inclusion model (C12/CDG).

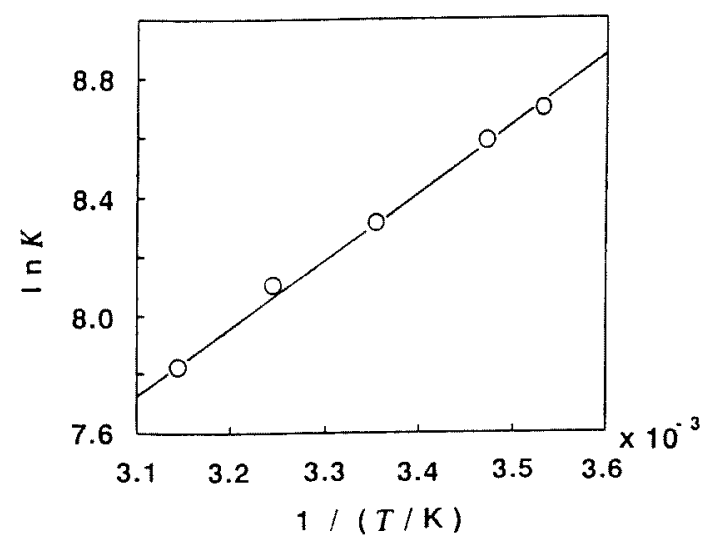

Fig. 9 Van't Hoff's plot of binding constant(C6/CDA).

Table 3 Thermodynamic Quantities of Binding

\begin{tabular}{rcc}
\hline D/CD & $\Delta H / \mathrm{kJ} \cdot \mathrm{mol}^{-1}$ & $\Delta S / \mathrm{J} \cdot \mathrm{mol}^{-1} \cdot \mathrm{K}^{-1}$ \\
\hline C6 CDA & -18.6 & 6.7 \\
C6 CDB & -64.7 & -143.0 \\
C6 CDG & -13.5 & 10.5 \\
C12 CDA & -15.3 & 28.7 \\
C12 CDB & -9.6 & 39.3 \\
C12 CDG & -57.7 & -100.3 \\
\hline
\end{tabular}

C12を比べるとアルキル基が結合に大きく貢献すること は明確であるがC 6 と C12を比較すると，アルキル基が 長くなると大きいK 值を与文るとは限らない。Kの値

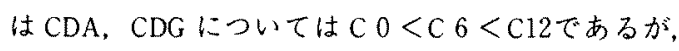
CDBについては $\mathrm{C} 0<\mathrm{C12}<\mathrm{C} 6$ である。

またC12について見れば $\mathrm{CDB}<\mathrm{CDA}<\mathrm{CDG}$ の順であ ク、C6については $\mathrm{CDG}<\mathrm{CDA}<\mathrm{CDB}$ であるこの結 果からアルキル基のかさ高さと CDの空洞の大きさとの 適合性が示唆される。用いた 3 種の CD の空洞の大きさ は, 表 2 〔1〕のうに知られている。炭素数 12 のアルキ ル鎖の屈曲性は， $\mathrm{CDG}$ の灴洞径に対する包接結合に有 利に動き，屈曲性の少ない炭素数6については適合性に 欠け緩い結合となるのであうう。このように考察し、ス ペクトル变化をも考虑して結合体（包接体）の模型とし てC12について図8が想定できる。 


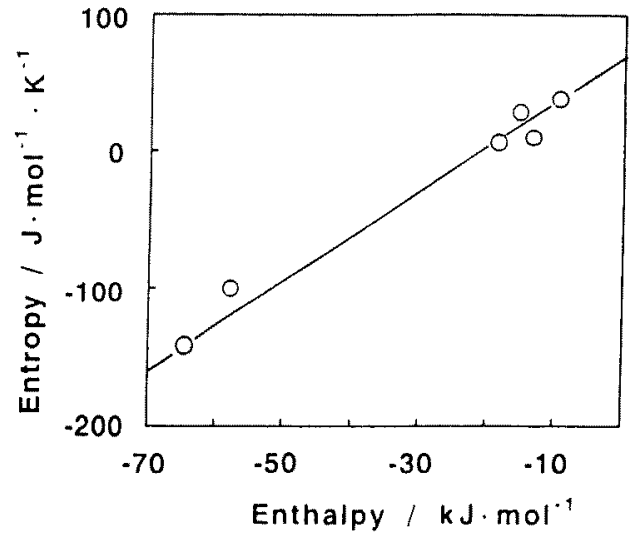

Fig. 10 Entropy-enthalpy compensation.

包接化合物の形成は一般にエンタルピー的に有利で, エントロピー的には不利（有利としても僅か）な過程で あり、この有利なエンタルピー变化への寄与の素過程は、 (1)ファンデルワールス相互作用，(2)ゲスト化合物と CD の水酸基との水素結合，(3)CD 空洞内の不安定な水分子 の放出，(4)CDの分子環のひずみエネルギーの解放であ るとされている[1]。表 1 の $K$ の温度変化から，ファン トホゥフの関係（図 9) を用いて結合エンタルピー（ $H)$, 結合エントロピー ( $\Delta S)$ が得られる。これらの熱 力学量を表 3 に与える。全体の值牥，エントロピー・エ ンタルピーの補償関係を示す（図10）。この補償関係は 化学平衡反応に広く見られ，理論化の試みもある[28]。 $\mathrm{CD}$ とこはく酸類との相互作用系 $[29]$ ，染料と水溶性高 分子との相互作用系[30]についての報告例が見られる。

ここで用いた系の包接結合はすべて発熹反応であり， そのうえに, C $6 / \mathrm{CDB}, \mathrm{C} 12 / \mathrm{CDG}$ 以外ではエントロ ピー増大による，付加的な安定化を伴う。このエントロ ピー增加加ら, 圶洞内の水分子の放出, 染料のアルキル

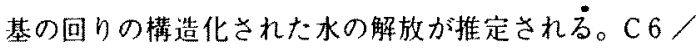
$\mathrm{CDB}, \mathrm{C} 12 / \mathrm{CDG}$ に見られる結合エントロピーの大きな 負值は，前記の空洞への祭密な適合に起因し，自由工ネ

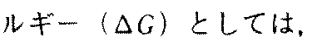

$$
\Delta G=\Delta H-T \cdot \Delta S
$$

の関倸により，繁密な適合に伴う大きな発熱によって補 われるのであろう。

\section{4. 結 語}

異なるアルキル鎖長を持つ酸性アゾ染料と $\alpha$ 一, $\beta \cdots$, $\gamma$-シクロデキストリン（CD）との相互作用を吸収スぺ タトルによって調へ，次のことが明らかになった。

1. $\mathrm{CD}$ の添加により吸収スペクトルが変化し，その変 化量は $\mathrm{C} 0<\mathrm{C} 6<\mathrm{Cl} 2$ の順に大きい。
2. 連続変化法により染料と CDの結合が $\mathrm{n} ： \mathbf{n}$ (等モ ル比）であることがわかった。CD の灙度を増大し た場合の分子吸光係数の変化を $\mathrm{n}=1$ の仮定で導い た式を用い，非線形最小二乗法の計算によって良く 再現できることを見い出し，結合は $1 ： 1$ の包接型 であると結論してそのモデルを提唱し，結合定数を 求めた。

3. 結合は発熱反応であり，結合のエンタルピーとエン トロピーは補償関係にあることがわかった。

4. 結合にはアルキル鎖長が影掣し，CDの空洞の大き さとの適合性が指摘された。

\section{文献}

1. M. L. Bender and M. Komiyama, "Cyclodextrin Chemistry Reactivity and Structure". Springer Verlag, 1978 ; 平井英史, 小宮山真訳，「シクロデキストリ ンの化学」, 学会出版センター, p.17, (1983).

2. 竹本喜一, 「包接化合物の化学」, 東京化学同人, p.44, (1969).

3. 中村信之、サイクロデキストリンの製造とその利用 ; 中村亦夫監修「水溶性高分子 3 版」, 化学工業社, p.423 (1990).

4. ダイヤモンド社技術情報編集部，化学と工業，46, 1224 (1993).

5. T. Seo, T. Kajihara, and T. Iijima, Makromol. Chem., 191. 1665 (1990).

6. T. Seo, T. Kajihara, K. Miwa, and T. Iijima, Makromol. Chem., 192, 2357 (1991)

7. T. Seo, T. Kajihara, and T. Iijima, Makromol. Chem., 188. 2071 (1987).

8. 委原宣洋, 屋教幾雄, 加工技術, 24，774（1989）.

9. H.J. Buschmann, D. Knittel, and E. Schollmeyer, Mel. liand Textilber., 72, 198 (1991).

10. 漇沢崇男，浜寄卓哉，佐々木路登，日化誌，1975， 2171 ; 渋沢崇男, 絨維学会予稿集, 1993，S-243.

11. H.J. Buschmann, D. Knittel, and E. Schollmeyer, Mel. liand Textilber., 72. 1012 (1991).

12. 樫野悦子，藤井富美子，家政誌，44，855（1993）。

13. E. Junquera, G. Tardaios, and E. Aicart, Langmuir, 9 , 1213 (1993).

14. K. Harata, Bull. Chem. Soc. Jpn., 49, 1493 (1976).

15. R. L. VanEtten et al., J., Am. Chem. Soc., 89, 3242 (1967); J. Am. Chem. Soc, 89, 3253 (1967)

16. K. M. Tawarah, Dyes Pigm., 19. 59 (1992).

17. A. Hersey and B. H. Robinson, J. Chem. Soc., (Faraday Trans. I), 80, 2039 (1984). 
18. Y. Matsui and K. Mochida, Bull. Chem. Soc. Jpn.. 51, 673 (1978).

19. R. J. Clarke, J. H. Coates, and S. F. Lincolin, J. Js. Chem. Soc. (Faraday Trans. I), 82, 2333 (1986).

20．須藤幸恵，饭島俊郎，䄉学誌，48，481（1992）。

21. 軽部幸恵, 饭島俊郎, 轹学誌, 50, 38 (1994)，

22. 日本学術振興会編, 「新染色加工講座 第 3 巻」, 共 立出版, p.190 (1972).

23. H. Schlenk and D. M. Sand, J. Am. Chem. Soc., 83, 2312 (1961).

24. R. I. Gelb, et al., J. Am. Chem. Soc., 100, 3553 (1978).

25. A. C. Kenneth, "Binding Constants, The Measurement of Molecular Complex Stability", John Wiley \& Sons, p.21 (1989).

26. H. A. Benesi and J. H. Hildebrand, J. Am. Chem. Soc., 71, 2703 (1949).

27. K.Miyajima, M. Sawada, and M. Nakagaki, Bull. Chem. Soc. Jpm., 56, 3556 (1983).

28.H. M. J. Boots and P. H. de Bokx, J. Phy. Chem., 93. 8240 (1989)

29. K. Uekama et al., Chem. Pharm. Bull., 23, 1421 (1975).

30. K. Hamada, T. Hirano, K. Yamada, and M. Mitsuishi, Dyes Pigm., 22, 151 (1993) 